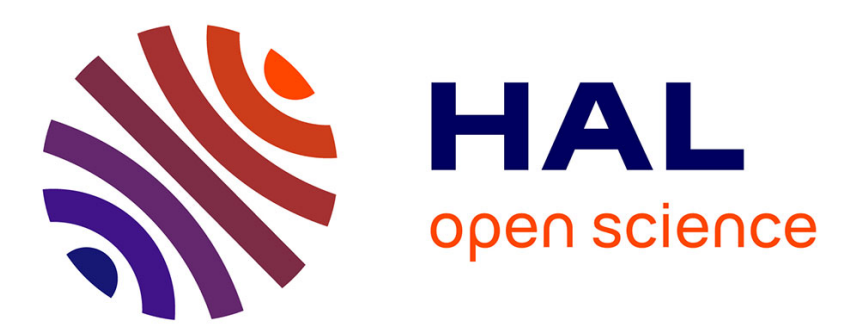

\title{
Effects of pruning and stand density on the productionof new epicormic shoots in young stands of pedunculate oak (Quercus robur L.)
}

Giulia Attocchi

\section{- To cite this version:}

Giulia Attocchi. Effects of pruning and stand density on the productionof new epicormic shoots in young stands of pedunculate oak (Quercus robur L.). Annals of Forest Science, 2013, 70 (7), pp.663673. 10.1007/s13595-013-0309-5 . hal-01201510

\author{
HAL Id: hal-01201510 \\ https://hal.science/hal-01201510
}

Submitted on 17 Sep 2015

HAL is a multi-disciplinary open access archive for the deposit and dissemination of scientific research documents, whether they are published or not. The documents may come from teaching and research institutions in France or abroad, or from public or private research centers.
L'archive ouverte pluridisciplinaire HAL, est destinée au dépôt et à la diffusion de documents scientifiques de niveau recherche, publiés ou non, émanant des établissements d'enseignement et de recherche français ou étrangers, des laboratoires publics ou privés. 


\title{
Effects of pruning and stand density on the production of new epicormic shoots in young stands of pedunculate oak (Quercus robur L.)
}

\author{
Giulia Attocchi
}

Received: 22 March 2013 / Accepted: 13 June 2013 /Published online: 2 July 2013

(C) INRA and Springer-Verlag France 2013

\begin{abstract}
- Context Avoidance or control of epicormic shoots is among the major silvicultural challenges for the production of high-quality oak timber. In northern Europe, contemporary oak silviculture aims to produce valuable timber on a relatively short rotation, applying early, heavy thinning combined with artificial pruning.

- Aims The aim of this study was to analyse the effects of pruning and stand density on the production of new epicormic shoots on young trees of pedunculate oak (Quercus robur L.). - Methods The study was based on two field experiments in even-aged stands of pedunculate oak subjected to different thinning practices and early selection of potential future crop trees. From ages 13 to 15 years, stem density was reduced to 300 trees $\mathrm{ha}^{-1}, 1,000 \mathrm{ha}^{-1}$ or stands remained unthinned. Pruning was conducted on selected trees at ages $22-24$ years. At that age, the stem density in unthinned control plots ranged from 2,500 to $3,100 \mathrm{ha}^{-1}$. All treatments were replicated twice within each experiment.

- Results Pruning led to an overall increase in the total production of new epicormic shoots. More epicormic shoots were produced in the lower part of the stem ( $0-3 \mathrm{~m}$ in height $)$ than in the upper part (3-6 m). The number of new epicormic shoots increased with increasing stand density.

- Conclusion Early, heavy thinning combined with high pruning at regular intervals may help shorten the rotation length for pedunculate oak without further reduction in wood quality than that which is caused by wider annual growth rings.
\end{abstract}

Handling Editor: Jean-Michel Leban

G. Attocchi $(\triangle)$

Southern Swedish Forest Research Centre, Swedish University

of Agricultural Sciences, Rörsjövägen 1, P.O. Box 49,

23053 Alnarp, Sweden

e-mail: giulia.attocchi@slu.se
Keywords Epicormic shoots · Pedunculate oak · Pruning · Stand density $\cdot$ Thinning practice

\section{Introduction}

One of the main objectives in managing oak forests is to produce high-quality timber. Several national, regional and industrial standards exist in order to define $\log$ quality. In spite of substantial variations in these standards, there are commonly accepted characteristics that identify the quality of a log, namely diameter, straightness, (absence of) rot, shake and cracks, ring width and number of epicormic shoots. The last feature is the object of this study.

Epicormic shoots are undesirable because they decrease timber quality by causing variations or defects in the wood known as 'pin knots' and 'cat's paw' (Evans 1984; Ståål 1986). Although some knots from epicormic shoots are accepted even in best lumber grades, their presence cannot usually be ignored. According to appearance grading by the commonly agreed European standard EN 975-1 (2009) one sound knot, less than $10 \mathrm{~mm}$, is permitted in standard sized pieces of the best grade. Since the production of high-quality oak timber requires a large investment and in addition the management is very intensive, it is therefore desirable to avoid or lower the risk of defects such as epicormic shoots.

There are different types of epicormic shoots, single shoots and clusters, which have an associated but sometimes varying terminology. Epicormic shoots are also called secondary branches (in contrast to primary branches), epicormic branches or more generally epicormics. Epicormic shoots develop from adventitious or proventitious buds (Evans 1984; Fink 1983; Fontaine et al. 1999). Adventitious buds develop externally from the usual order of time and position and cannot be traced to a leaf axil. Proventitious buds originate from primary buds and can be traced to the pith of the main stem; they are also 
called dormant buds because they may not develop into epicormic shoots or branches. There is general agreement about the origin of epicormic shoots in oak trees; an exhaustive description of how different types form and develop is well documented (Fontaine et al. 2001, 2004; Meier et al. 2012).

There is a high degree of heritability in the tendency to form epicormic buds (Savill and Kanowski 1993). It is generally recognised that pedunculate oak (Quercus robur L.) produces more epicormic shoots than sessile oak (Quercus petraea (Matt.) Liebl.) (Evans 1982; Jensen 2000). Recent studies have improved the understanding of ontogenetic processes which trigger the emergence of epicormic branches and influence their composition in temperate broadleaved tree species, such as the pedunculate oak (Morisset et al. 2011a) and sessile oak (Colin et al. 2010; Fontaine et al. 1999; Morisset et al. 2012). It has been found that the number of visible epicormic buds is a reliable indicator of future epicormic shoot formation (Fontaine et al. 2001; Roussel 1978).

In contrast, physiological processes and environmental factors that promote or suppress the emergence and development of epicormic shoots are not entirely understood (Bary-Lenger and Nebout 1993; Colin et al. 2010; Harmer 1990). However, it has been identified (e.g. Bary-Lenger and Nebout 1993; Evans 1982) that epicormic shoots may appear as a response to stress, e.g. disease, change in competitive status, recent thinning intervention, pruning or water balance dynamics. Light has often been at the centre of the discussion among environmental factors (Evans 1982; Roussel 1978; Spiecker 1991; Wignall and Browning 1988), but the mechanisms that trigger the formation of epicormic buds and the emergence of epicormic shoots remain unknown.

Light, in particular, does not adequately explain the initial formation of epicormic buds, but increased levels of light or intensity will cause epicormic shoots to develop and grow more vigorously (Evans 1982). It has been observed that new shoots appear in response to thinning, due to increased light, but then gradually die as canopy closure increases (Spiecker 1991).

Light regulation has been shown, through thinnings, to play a fundamental role in the survival of epicormic shoots, for example, in the French practice of light crown thinning. This is applied during long rotations (200 years or more) where the main purpose is to obtain an essentially constant radial growth rate and a shading of the stem which limits the development of epicormic shoots (Bary-Lenger and Nebout 1993; Jarret 2004; Sardin 2008). Another indirect method to prevent epicormic shoots is the promotion or introduction of an understorey of shade-tolerant tree or bush species. This decreases light levels in the later stages of the rotation by shading lower parts of the overstorey tree trunks and is often done at age 40-50 years. This method has been shown to be an effective means against the development of epicormic shoots (Henriksen and Sanojca 1983; Morisset et al. 2011b).
A direct, mechanical method to control the development of epicormic shoots is pruning. Pruning removes epicormic shoots, but does not prevent their emergence, as these are triggered by a change in auxin quantity or distribution within the tree (Meier et al. 2012; Roussel 1978) or the initiation, which is influenced and regulated by environmental factors. It is generally believed that pruning itself may trigger the development of additional epicormic shoots, which form at the callus of pruning wounds (Spiecker 1991). However, an investigation into different combinations of pruning time and frequency over a 4-year period displayed inconsistencies in the short-term production of new epicormic shoots on 50year-old pedunculate oak (Kerr and Harmer 2001). This supports, at least on an experimental basis, that regular inspection and pruning for the long-term control of epicormic shoots are required (Skovsgaard 2004a, b).

Pruning at regular intervals was introduced into forestry practice by leading oak managers in northern Europe during the mid-1900s (Carbonnier 1975; Henriksen 1988; Jobling and Pearce 1977; Staun 1989; Ståål 1986), but in some places, pruning was stopped due to increasing costs. Recently, however, pruning has gained interest again due to contemporary idea of so-called free growth regimes for oak (Jensen and Skovsgaard 2009; Jobling and Pearce 1977; Kerr 1996; Lemaire 2010; Stern 1973). The concept is to keep the crowns of pre-selected future crop trees free to grow at all times, to increase or possibly maximize stem growth and thereby shorten the rotation. Consequently, artificial pruning becomes essential when the production of high-quality timber is the main objective. This is in contrast to the traditional light thinning practices used in France (Bary-Lenger and Nebout 1993; Jarret 2004; Sardin 2008) and Germany (Kenk 1993; Röhrig et al. 2006), where pruning is not widely carried out.

For practical purposes, three distinct processes of epicormic shoots formation can be identified: initiation, emergence and growth. Silviculture can do little to influence the initiation and emergence; furthermore, oaks have an individual predisposition to bear epicormic shoots (Savill and Kanowski 1993). On the other hand, silviculture can help control the growth and persistence of epicormic shoots, through annual stem inspections for epicormic shoots and the selection of crop trees bearing no or few epicormic shoots and promotion of an understorey or pruning.

The objective of this study was to quantify the effects of pruning and thinning practice expressed by residual stem number (stand density) on the production of new epicormic shoots in even-aged plantations of young pedunculate oak, including epicormic location along the stem. The research hypotheses were: (1) pruning reduces the number of new epicormic shoots compared to un-pruned oak trees (H1); (2) the number of new epicormic shoots decreases with an increasing stand density (H2); and (3) the number of new epicormic shoots increases with increasing height up the stem (H3). 


\section{Materials and methods}

\subsection{Experiments and stand description}

The study was based on selected plots within two statistically designed thinning experiments (Table 1) in young stands of pedunculate oak in Denmark. Both experiments are located on a glacial till and receive an average annual rainfall of $650 \mathrm{~mm}$.

Experiment 1516 is located in the forest Haslev Orned of Bregentved Estate (Universal Transverse Mercator (UTM) coordinates, ETRS89, zone 32: E 689,290 m, N 6,135,994 m; elevation approximately $33 \mathrm{~m}$ above sea level), approximately $60 \mathrm{~km}$ south of Copenhagen (Rune and Skovsgaard 2007; Jensen and Skovsgaard 2009). The stand was established in spring 1989 by sowing on a former meadow, using 90-95 kg of acorns per hectare. Seeds had been collected in local stands (seed sources F.661 and F.630) of Dutch origin. The area was fenced for approximately 10 years. The experiment began in spring 2002 at age 13 years. At installation, the stem number before thinning ranged from 6,500 to 7,000 trees ha ${ }^{-1}$, and the stand height was approximately $5.5 \mathrm{~m}$.

Experiment 1517 is located in Brendstrup forest of Aarhus Municipality (UTM coordinates, ETRS89, zone 32: Block East at E 571,937 m, N 6,227,304 m, elevation approximately $59 \mathrm{~m}$ above sea level, and Block West at E 571,040 m, N $6,227,081 \mathrm{~m}$, elevation approximately $68 \mathrm{~m}$ above sea level), approximately $5 \mathrm{~km}$ northwest of Aarhus. Block East of the experiment was established in the late autumn of 1990 by planting 2-year-old seedlings on former agricultural land. The genetic origin of this planting is Petersgaard F.181. Block West of the experiment was planted in 1991 on a former agricultural land using 2-year-old seedlings. It is believed that the genetic origin of this part of the experiment is Pederstrup F.369, but possibly with an admixture of Petersgaard F.181, Stensballegaard F.484 or Haderslev F.286. These two blocks remained unfenced and numerous trees were badly damaged from browsing by European hare (Lepus europaeus Pallas). The thinning experiment was installed during autumn 2003 at age 15 years. At installation, the stem number before thinning ranged from 5,300 to 5,800 trees $\mathrm{ha}^{-1}$ and the stand height was approximately $6.0 \mathrm{~m}$.

Both experiments are part of a national Danish series of experiments on thinning in even-aged oak stands. The experimental designs of 1516 and 1517 are identical and include eight treatments with different combinations of precommercial thinning grade and time of first pre-commercial thinning. All thinning treatments were replicated twice within each experiment in a randomized block design. For the purpose of this investigation, only three thinning treatments were considered, which are identified by their residual stem number, namely the strictly unthinned control and plots thinned to densities of 1,000 or 300 trees $\mathrm{ha}^{-1}$.

\subsection{Sampled trees}

To test the effects of pruning on epicormic sprout production (H1), only plots thinned to a residual stem density of 1,000 trees $\mathrm{ha}^{-1}$ were used. Pruning was applied to 100 evenly distributed crop trees per hectare during early spring 2011.

Table 1 Stand values in spring 2011

\begin{tabular}{|c|c|c|c|c|c|c|c|c|c|c|c|c|}
\hline \multirow[t]{3}{*}{ Experiment } & \multirow[t]{3}{*}{ Treatment } & \multirow[t]{3}{*}{ Block/plot } & \multirow[t]{3}{*}{ Age $^{\mathrm{a}}$ (years) } & \multirow[t]{3}{*}{ Area (ha) } & \multirow[t]{3}{*}{$\mathrm{N}\left(\mathrm{ha}^{-1}\right)$} & \multirow{3}{*}{$\begin{array}{l}\text { Basal area } \\
\left(\mathrm{m}^{2} \mathrm{ha}^{-1}\right)\end{array}$} & \multirow{2}{*}{\multicolumn{2}{|c|}{$\frac{\mathrm{DBH}}{(\mathrm{cm})}$}} & \multirow{2}{*}{\multicolumn{2}{|c|}{$\frac{\mathrm{H}}{(\mathrm{m})}$}} & \multirow{2}{*}{\multicolumn{2}{|c|}{$\frac{\text { LLB }}{(\mathrm{m})}$}} \\
\hline & & & & & & & & & & & & \\
\hline & & & & & & & Mean & SE & Mean & SE & Mean & $\mathrm{SE}$ \\
\hline \multirow[t]{6}{*}{1516} & \multirow[t]{2}{*}{ Control } & East/M & 22 & 0.13 & 2,973 & 25.31 & 10.0 & 0.16 & 11.1 & 0.16 & 4.8 & 1.63 \\
\hline & & West/A & 22 & 0.18 & 2,479 & 24.70 & 10.9 & 0.16 & 11.1 & 0.14 & 4.7 & 1.59 \\
\hline & \multirow[t]{2}{*}{1,000} & East/N & 22 & 0.13 & 963 & 16.11 & 14.3 & 0.24 & 10.4 & 0.14 & 3.6 & 0.84 \\
\hline & & West/D & 22 & 0.24 & 961 & 15.03 & 13.8 & 0.19 & 11.1 & 0.10 & 3.8 & 0.94 \\
\hline & \multirow[t]{2}{*}{300} & East/O & 22 & 0.12 & 300 & 7.84 & 17.3 & 0.41 & 9.5 & 0.13 & 2.2 & 0.47 \\
\hline & & West/C & 22 & 0.31 & 310 & 7.21 & 17.7 & 0.30 & 10.3 & 0.12 & 2.3 & 0.77 \\
\hline \multirow[t]{6}{*}{1517} & \multirow[t]{2}{*}{ Control } & East/A & 23 & 0.25 & 3,084 & 24.71 & 9.7 & 1.04 & 9.7 & 0.09 & 5.3 & 0.36 \\
\hline & & West/L & 23 & 0.24 & 3,083 & 24.93 & 9.7 & 1.13 & 10.4 & 0.11 & 4.4 & 0.40 \\
\hline & \multirow[t]{2}{*}{1,000} & East/E & 23 & 0.25 & 1,024 & 14.54 & 13.1 & 1.95 & 9.6 & 0.08 & 3.0 & 0.28 \\
\hline & & West/K & 23 & 0.24 & 958 & 13.68 & 13.2 & 1.76 & 9.7 & 0.07 & 3.1 & 0.26 \\
\hline & \multirow[t]{2}{*}{300} & East/B & 23 & 0.25 & 324 & 6.59 & 15.9 & 2.82 & 9.3 & 0.12 & 3.3 & 0.37 \\
\hline & & West/N & 23 & 0.30 & 329 & 6.96 & 16.2 & 2.85 & 9.3 & 0.11 & 2.4 & 0.22 \\
\hline
\end{tabular}

$D B H$ mean diameter at breast height, $H$ mean height, $L L B$ lowest living branch

${ }^{\text {a }}$ At the time of assessment 
The selection of crop trees was based on qualitative criteria as well as spatial distribution. Here, primary branches and epicormic shoots (secondary branches) present on the lower $6 \mathrm{~m}$ of the stem were removed using a manual pruning saw mounted on a 6-m telescopic pole. Two pruning methods were used, natural target pruning and flush cut (O'hara 2007), but the differences were not tested in this study and this will be analysed in another study. Pruning height was controlled by a second operator using a telescopic measuring tape. Epicormic shoots were inspected on a sample of crop trees (Table 2).

To test the effects of stand density on epicormic sprout production $(\mathrm{H} 2)$, plots from three thinning treatments were considered, including the un-pruned trees used in the previous analysis. These were the unthinned control plots and plots thinned to a residual stem number of 1,000 or 300 trees $\mathrm{ha}^{-1}$.

The difference in epicormic emergence in relation to height up the stem (H3) was tested in relation to pruning and stand density; therefore, the plots used for $\mathrm{H} 1$ and $\mathrm{H} 2$ were also used in testing $\mathrm{H} 3$.

In each plot, 10-12 pruned and 10-17 un-pruned trees were sampled and investigated for their frequency and location of epicormic shoots (Table 2). Sampling was conducted through stratification based on prior observations of flushing time and diameter class. The observations of flushing took place during 2006, 2007 and 2011 on specific trees and at regular intervals (same calendar date), from the last week of April until the last week of May. Four strata, defined by time and speed of flushing, were identified: early-fast, early-slow, late-fast or late-slow. Information about flushing was not directly used in the analysis, but only during the sampling procedure to eliminate a possible (but unknown) influence of the phenological behaviour of trees on the emergence of epicormic shoots. Trees were selected within each stratum, and the diameter at breast height (DBH) was also considered. Five-diameter classes were created from quintiles based on the DBH distribution for each plot and in most cases two trees from each DBH class were selected.

\subsection{Tree description}

Standard forestry measurements were taken in all plots in March 2011 (Table 1). Additional data were recorded for all pruned trees in treatment 1,000 , namely height above ground of the lowest living branch before and after pruning (LLB and NLB, respectively), a count of the number of primary, living branches $(\mathrm{Nb})$ and epicormic shoots $(\mathrm{Ne})$ which were pruned and cross diameter of the collar of the thickest branch pruned (Table 3).

In July 2011, newly flushed epicormic shoots were counted on all sample trees on the lower $6 \mathrm{~m}$ of the stem. Prior to counting, each stem was divided into six 1-m sections using a ladder and a telescopic measuring tape; sections were delimited using ribbons. On each 1-m section, different types of new epicormic shoots were counted using a three-class tally list: new single shoots (Nes), number of shoots originating from a cluster and number of clusters (Pec) (a cluster is considered to have at least two epicormic shoots). Due to budget restrictions, epicormic buds were not considered.

\subsection{Statistical analysis}

The three research hypotheses were evaluated with mixed linear models (Zuur et al. 2009; West et al. 2007) under the usual assumption of identically, normally distributed errors
Table 2 Number of trees sampled for inventory of epicormic branches in each plot

\begin{tabular}{llllll}
\hline Experiment & Block & Treatment & Pruned & Not pruned & Total \\
\hline 1516 & East & Unthinned & - & 10 & 10 \\
& East & 300 & - & 10 & 10 \\
East & 1,000 & 10 & 10 & 20 \\
West & Unthinned & - & 14 & 14 \\
& West & 300 & - & 10 & 10 \\
& West & 1,000 & 10 & 17 & 27 \\
& & & Subtotal 1516 & 91 \\
& East & Unthinned & - & 10 & 10 \\
& East & 300 & - & 10 & 10 \\
East & 1,000 & 10 & 10 & 20 \\
West & Unthinned & - & 10 & 10 \\
West & 300 & - & 13 & 13 \\
& West & 1,000 & 12 & 14 & 26 \\
& & & Subtotal 1517 & 89 \\
& & & Total & 180 \\
\hline
\end{tabular}


Table 3 Crop tree attributes for plots of 1,000 trees $\mathrm{ha}^{-1}$, where pruning was applied at the beginning of 2011

\begin{tabular}{|c|c|c|c|c|c|c|c|c|c|c|c|c|c|c|c|c|c|}
\hline \multirow[t]{3}{*}{ Exp } & & \multirow{2}{*}{\multicolumn{2}{|c|}{$\frac{\mathrm{DBH}}{(\mathrm{cm})}$}} & \multirow{2}{*}{\multicolumn{2}{|c|}{$\frac{\mathrm{H}}{(\mathrm{m})}$}} & \multirow{2}{*}{\multicolumn{2}{|c|}{$\frac{\text { LLB }}{(\mathrm{m})}$}} & \multirow{2}{*}{\multicolumn{2}{|c|}{$\frac{\mathrm{NLB}}{(\mathrm{m})}$}} & \multirow{2}{*}{\multicolumn{2}{|c|}{$\frac{\text { Area collar }}{\left(\mathrm{cm}^{2}\right)}$}} & \multirow{2}{*}{\multicolumn{2}{|c|}{$\frac{\mathrm{Nb}}{\text { (count) }}$}} & \multirow{2}{*}{\multicolumn{2}{|c|}{$\frac{\mathrm{Ne}}{\text { (count) }}$}} & \multirow{2}{*}{\multicolumn{2}{|c|}{$\frac{T_{\text {epi }}}{\text { (count) }}$}} \\
\hline & & & & & & & & & & & & & & & & & \\
\hline & & Mean & SE & Mean & SE & Mean & SE & Mean & SE & Mean & SE & Mean & SE & Mean & $\mathrm{SE}$ & Mean & SE \\
\hline \multirow[t]{4}{*}{1516} & Pruned & 15.6 & 0.66 & 11.0 & 0.30 & 3.4 & 0.33 & 5.6 & 0.15 & 55.1 & 3.96 & 6.0 & 0.54 & 1.2 & 0.59 & 32.2 & 4.64 \\
\hline & Not pruned & 14.0 & 1.09 & 9.7 & 0.39 & 3.8 & 0.36 & - & - & - & - & - & - & - & - & 20.4 & 2.88 \\
\hline & Pruned & 16.3 & 0.79 & 11.9 & 0.26 & 3.8 & 0.24 & 5.8 & 0.12 & 78.6 & 8.43 & 5.3 & 0.41 & 2.9 & 0.70 & 26.5 & 2.90 \\
\hline & Not pruned & 14.4 & 0.86 & 10.6 & 0.34 & 3.4 & 0.36 & - & - & - & - & - & - & - & - & 36.9 & 1.68 \\
\hline \multirow[t]{4}{*}{1517} & Pruned & 15.0 & 0.64 & 10.4 & 0.36 & 3.2 & 0.29 & 5.7 & 0.09 & 79.5 & 11.19 & 6.7 & 0.66 & 0.9 & 0.27 & 12.1 & 1.14 \\
\hline & Not pruned & 12.7 & 0.96 & 9.0 & 0.21 & 3.2 & 0.51 & - & - & - & - & - & - & - & - & 27.8 & 4.53 \\
\hline & Pruned & 15.6 & 0.59 & 9.9 & 0.19 & 4.6 & 0.25 & 5.8 & 0.09 & 73.4 & 8.04 & 7.9 & 0.50 & 0.7 & 0.41 & 24.3 & 2.27 \\
\hline & Not pruned & 14.0 & 0.59 & 9.5 & 0.21 & 3.2 & 0.84 & - & - & - & - & - & - & - & - & 11.2 & 1.06 \\
\hline
\end{tabular}

$D B H$ diameter at breast height; $H$ height; $L L B$ lowest living branch; $N L B$ new lowest living branch after pruning; Area collar average area of the collar of the thickest branch pruned, approximated to the area of a circle; $N b$ number of living primary branches removed; $N e$ number of living epicormic branches removed; $T_{e p i}$ is the total number of epicormic shoots after pruning, given by the sum of new single shoots and points of origin

with zero mean and common variance and using complex nesting to take into account the three levels of split-plot design.

The total number of new epicormic shoots was analysed only for the pruned trees in plots of 1,000 stems ha ${ }^{-1}$, disregarding the spatial distribution along the stem. This preliminary analysis was performed to assess whether either the number of primary branches pruned or the biomass (foliage) removed influenced the overall production of new epicormic shoots (test of $\mathrm{H} 1$ ). The model used can be specified as $\mathrm{Tepi}_{i j}=\alpha+\mathrm{DBH}_{i j}+\mathrm{Nb}_{i j}+\mathrm{Ne}_{i j}+\mathrm{Lb}_{i j}+\operatorname{area}_{i j}+b_{j}+\varepsilon_{i j}$ where $\mathrm{Tepi}_{i j}$ is the total number of new epicormic shoots in tree $i$ of plot $j$; $\mathrm{DBH}_{i j}$ is the diameter at breast height; $\mathrm{Nb}_{i j}$ and $\mathrm{Ne}_{i j}$ are number of primary branches and epicormic shoots, respectively, before pruning; $\mathrm{Nb}_{i j}$ is the pruning intensity (NLBLLB); and area $_{i j}$ is the cross-sectional area of the collar of the thickest branch removed. The term $b_{j} \sim N\left(0, \sigma_{b}^{2}\right)$ is a random effect representing the within-plot variation. No size-based interactions were found and to ensure biologically sensible results, other interactions were disregarded.

In the analyses of $\mathrm{H} 1, \mathrm{H} 2$ and $\mathrm{H} 3$, the response variable was the total number of new epicormic shoots (Epi), obtained as the sum of Nes and Pec, while as fixed effects, pruning (pruned, un-pruned), stem section (0-1, 1-2 m, etc.), stand density (unthinned, 1,000 ha ${ }^{-1}, 300 \mathrm{ha}^{-1}$ ), DBH and total tree height $(\mathrm{H})$ were used. Due to the nested structure of data, plot and tree identity (nested in plot) were specified as random effects to correct for non-independence by imposing two-way nested correlation (within trees and within plots) in the model. Inspection of the residuals indicated violation of variance homogeneity. Therefore, heterogeneous residual variance structures were incorporated in each section, resulting in the general model:

$\mathrm{Epi}_{i j k}=X_{i j k} \times \beta+a_{k}+b_{j k}+\varepsilon_{i j k}$ where $\mathrm{Epi}_{i j k}$ is the number of new epicormic shoots in section $i$ of tree $j$ of plot $k ; X_{i j k} \times \beta$ is the fixed term, comprising the design matrix of predictor variables and a vector of fixed effects; $a_{k} \sim N\left(0, \sigma_{a}{ }^{2}\right)$ and $b_{j k} \sim N\left(0, \sigma_{b}{ }^{2}\right)$ are random effects representing the between- and within-plot variation, respectively; and $\varepsilon_{i j k} \sim N\left(0, \sigma_{s}^{2}\right)$ is the residual error, where $s$ refers to section number thereby allowing heterogeneity into the model, based on the variance covariate 'section'.

The optimal variance structure was estimated based on restricted maximum likelihood (REML) (West et al. 2007), using Akaike's information criteria and likelihood ratio test. The saturated model was refined by backwards stepwise elimination of non-significant terms, using maximum likelihood ratio test, based on an approximate $\chi^{2}$ distribution. The final model was presented using the REML. The original intention was to use a Poisson regression, based on the response variable as a count. The analyses were performed using the ' $R$ ' statistical and programming environment, version 2.14.2 ( $\mathrm{R}$ Core Team 2012) and the 'nlme' package for linear and nonlinear mixed effects models (Pinheiro et al. 2012).

\section{Results}

\subsection{Pruning effect}

The total number of new epicormic shoots per tree increased with pruning as a function, both of the number of primary branches and epicormic branches. The preliminary analysis of the total number of new epicormic shoots for the pruned trees showed that both primary branches and epicormic shoots removed at pruning were significant $(L=8.842, d f=1, p<0.05$ and $L=5.227, d f=1, p<0.05$, respectively). However, DBH, pruning efficiency and the area of the collar of the thickest 
branch were not significant at the $5 \%$ level. The coefficients of the final model Tepi $\mathrm{i}_{i j}=2.407 \times \mathrm{Nb}_{i j}+3.322 \times \mathrm{Ne}_{i j}$ indicate the relative importance of removal of epicormic shoots as well as of primary branches, both of which led to the production of additional, new epicormic shoots.

Pruning clearly influenced the composition of epicormic shoots (classified as single shoots or clusters) along the stem (Fig. 1). The average number of all types was higher in unpruned than pruned trees on the three stem sections below $3 \mathrm{~m}$ and vice versa for the three upper sections above $3 \mathrm{~m}$. Unpruned trees presented a consistent pattern of epicormic shoot types, increasing from below, peaking at the section 1-2 $\mathrm{m}$ and thereafter decreasing with increasing height up the stem. Pruned trees had a similar pattern up the stem and across epicormic shoot types, but fluctuated somewhat in the decrease of epicormics in the upper part of the stem towards $6 \mathrm{~m}$.

In relation to $\mathrm{H} 1$, the independent variable of the statistical analysis was obtained as a sum of new single shoots and points of origin (Fig. 2). There was a significant effect of pruning on the number of epicormic shoots and the interaction between sections was also significant $(L=18.257, d f=4$, $p<0.05$, Table 4). Due to collinearity, DBH and $\mathrm{H}$ were tested independently and were not significant components of the model at $5 \%$ level.

\subsection{Thinning effect}

The number of epicormic shoots decreased with decreasing stand density (Fig. 3). The control treatment had the highest frequency for all three types, with only two exceptions in section 1 of new single shoots and in section 2 of points of origin. Treatment 1,000 trees $\mathrm{ha}^{-1}$ had the second highest frequency, while treatment 300 trees $^{-1}$ had the lowest, except in sections 5 and 6 of new single shoots and points of origin. Similar to the pruning analysis, the independent variable for the thinning analysis was obtained as a sum of new single shoots and points of origins. Stand density and height along the stem had a significant influence on the number of new epicormic shoots on un-pruned trees, with a significant interaction $(L=18.814, d f=5, p<0.05)$.

A common model for all sections was estimated for the number of new epicormic shoots depending on stand density (Table 5 and Fig. 4). The number of new epicormic shoots was highest in section 2 for all stand densities, followed by sections 3 and 1 . The number of new epicormic shoots increased linearly with increasing stand density but with different slopes due to a significant interaction between stand density and stem section (i.e. height up the stem). Due to collinearity, DBH and $\mathrm{H}$ were tested independently and neither of these were significant $(L=2.533, d f=1, \mathrm{p}=0.111$ for $\mathrm{DBH} ; L=2.988, d f=1$, $p=0.083$ for $\mathrm{H})$.

\section{Discussion}

Pruning and thinning treatments were investigated for their effects on the production of epicormic shoots in oak in four replicated experimental plots. Not only was a significant effect detected, but also a similar pattern in the number and location of new epicormic shoots across sites and plot replications. This provides a strong basis from which to draw conclusions, even though it is difficult to outline the consequences
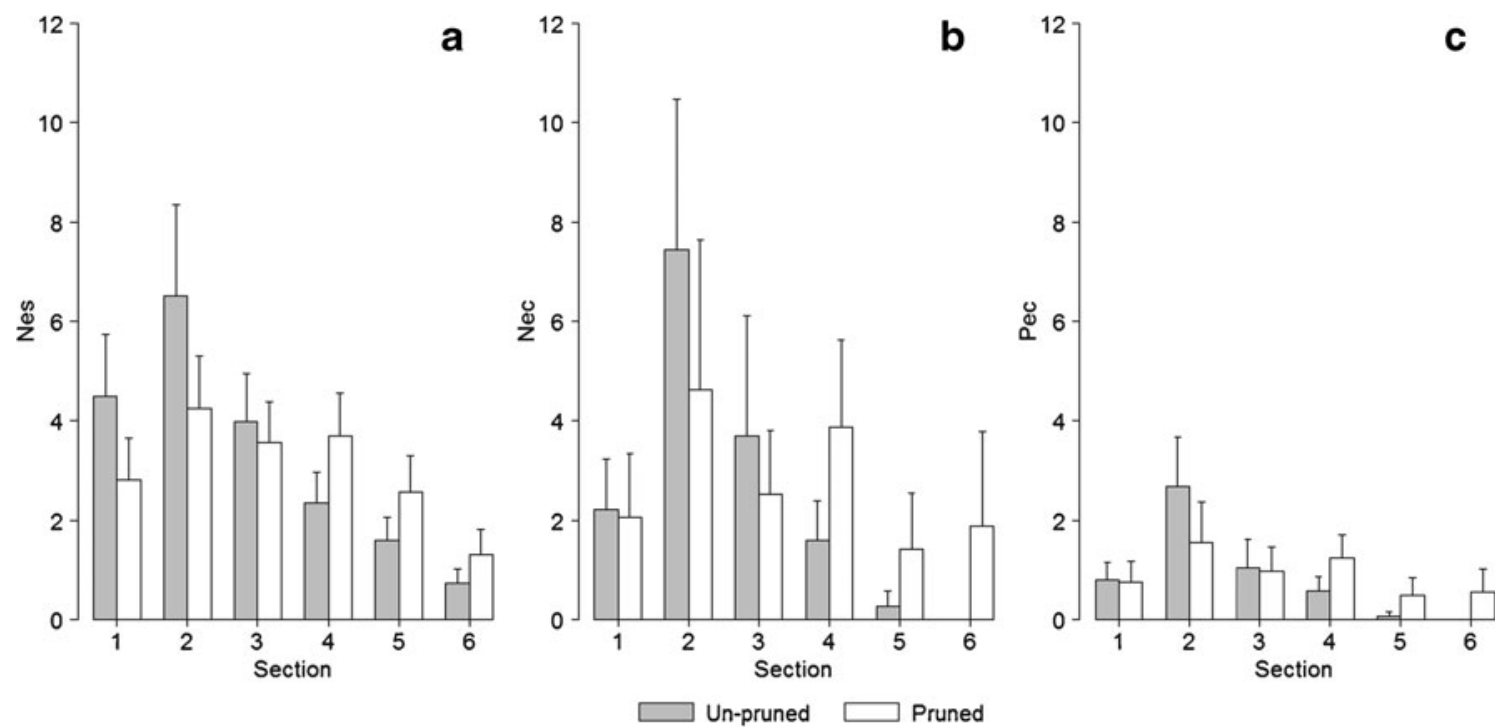

Fig. 1 Bar plot representing the mean number of different types of epicormic shoots on the lower six 1-m sections of the stem of pruned and un-pruned trees in treatment 1,000. Error bars indicate $95 \%$

confidence interval. Nes new single shoots (a), Nec number of shoots originating from a cluster (b), Pec number of points where multiple shoots originate from (points of origin) (c) 
Fig. 2 Boxplot of the number of pooled epicormic shoots counted on pruned trees (white bars) and un-pruned trees (grey bars) vs. stem section

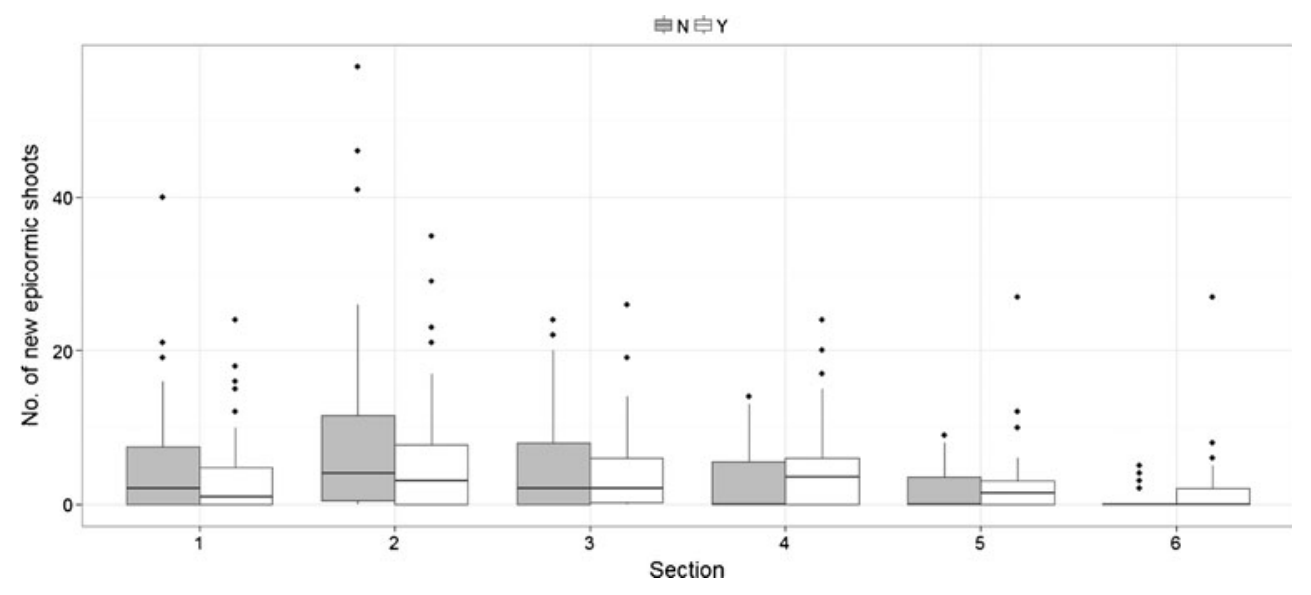

and implications for forest management due to the significant interactions encountered.

\subsection{Hypothesis no. 1}

According to hypothesis no. 1, pruning reduces the number of new epicormic shoots compared to un-pruned oak trees. In this study, an overall negative effect of pruning was detected, thus falsifying H1. Moreover, a detailed analysis revealed a significantly different distribution of epicormic shoots along the stem of pruned and un-pruned trees. The effect was dependant on stem section (height up the stem), with pruned trees developing less epicormic shoots in the lower part of the stem (below $3 \mathrm{~m}$ ) and more in the upper part (between 3 and $6 \mathrm{~m})$. This pattern was observed across both experiments. This significant interaction between pruning and height along the stem for forestry practice. Similar results were reported by Spiecker (1991) who for both pedunculate and sessile oak found that pruning leads to an increase in the number of epicormic shoots and therefore discouraged the practice. In contrast, Kerr and Harmer (2001) reported a general decrease in the production of epicormic shoots in pedunculate oak with pruning compared to the control plot.

For sessile oak, the number of visible epicormic buds and past epicormic emergences, present at a given time, is positively correlated to the subsequent frequency of epicormic shoots in sessile oak (Morisset et al. 2011a, 2012; Fontaine et al. 2001). For the purpose of this study, data on epicormic buds were not recorded; therefore, a possible correlation between the presence
Table 4 Summary of fixed, random and variance estimated parameters for the pruning analysis. The term treatment refers to pruning and was fitted as a nominal variable. The random effect $a_{k}$ representing the within tree variation is $N\left(0,0.0006^{2}\right)$ and the random effect $b_{j k}$ representing the between-tree variation is $N\left(0,3 \cdot 673^{2}\right)$. Estimates for the fixed effect for sections other than section 1 were estimated as an adjustment to the section 1 estimate

\begin{tabular}{llrlrrr}
\hline Fixed & Treatment & Estimate & SE & $d f$ & $t$ value & $p$ value \\
\hline Section 1 & Not pruned & 5.294 & 0.94 & 455 & 5.647 & 0.000 \\
Section 2 & Not pruned & -3.902 & 1.49 & 455 & 2.613 & 0.009 \\
Section 3 & Not pruned & 0.275 & 0.95 & 455 & -0.290 & 0.772 \\
Section 4 & Not pruned & 2.353 & 0.90 & 455 & -2.624 & 0.009 \\
Section 5 & Not pruned & 3.627 & 0.80 & 455 & -4.520 & 0.000 \\
Section 6 & Not pruned & 4.569 & 0.83 & 455 & -5.496 & 0.000 \\
Section 1 & Pruned & 3.571 & 1.40 & 455 & -1.235 & 0.220 \\
Section 2 & Pruned & -2.238 & 2.22 & 455 & -0.749 & 0.454 \\
Section 3 & Pruned & -0.976 & 1.41 & 455 & 0.888 & 0.375 \\
Section 4 & Pruned & -1.357 & 1.33 & 455 & 2.781 & 0.006 \\
Section 5 & Pruned & 0.500 & 1.19 & 455 & 2.619 & 0.009 \\
Section 6 & Pruned & 1.714 & 1.24 & 455 & 2.308 & 0.022 \\
Random-variance covariate & & & & & \\
$\sigma^{2}$ section 1 & & 31.332 & & & & \\
$\sigma^{2}$ section 2 & & 82.405 & & & & \\
$\sigma^{2}$ section 3 & & 14.382 & & & & \\
$\sigma^{2}$ section 4 & & 9.664 & & & & \\
$\sigma^{2}$ section 5 & & 3.907 & & & & \\
$\sigma^{2}$ section 6 & & & & & & \\
\hline
\end{tabular}



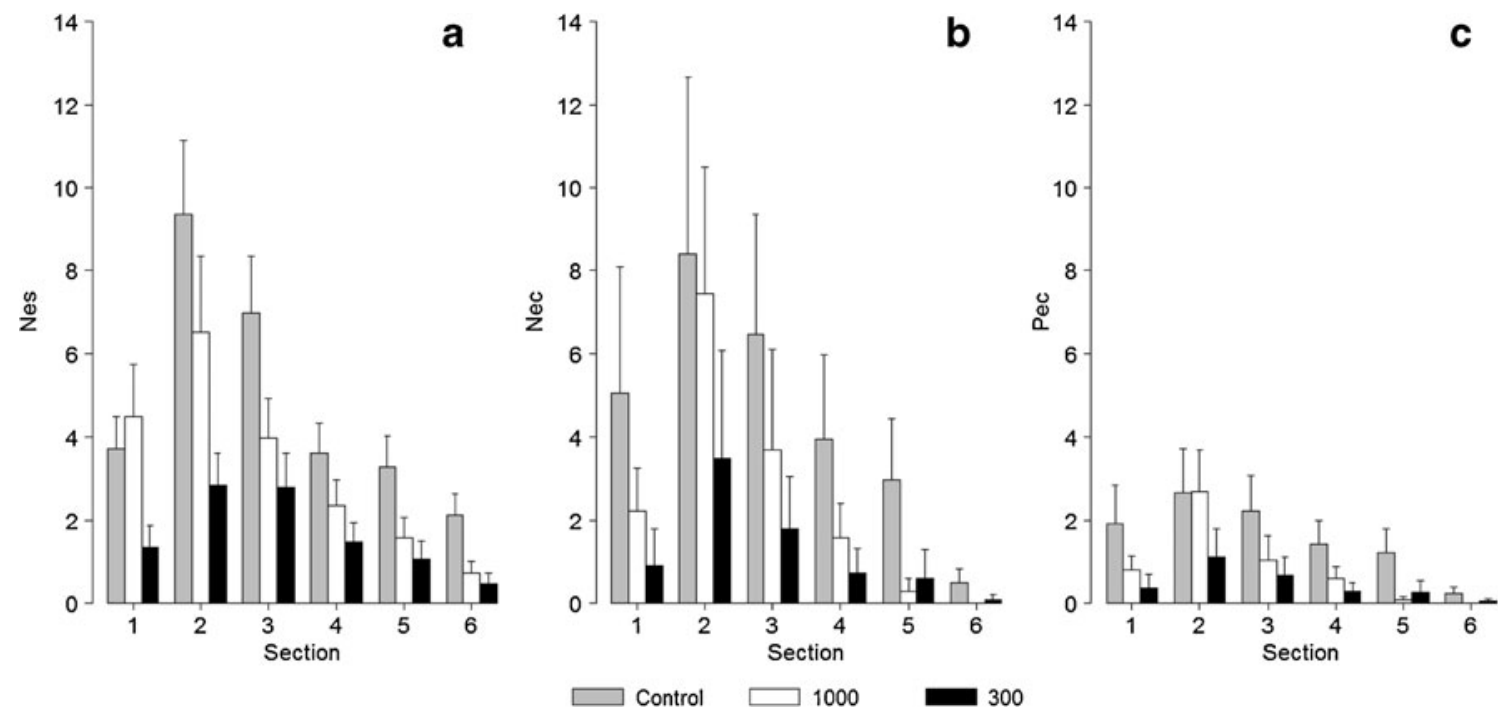

Fig. 3 Bar plot of the different types of epicormic shoots assessed vs. section, divided by different thinning treatments. Error bars indicate $95 \%$ confidence interval. Nes new single shoots (a); Nec number of

of dormant buds and pruning could not be established. However, the suggestion that buds may burst vigorously when a branch above is pruned, due to the release of internal physiological processes (Colin et al. 2010), may help explain these results. There are several additional ways through which pruning can trigger the emergence of more epicormic shoots. For example, pruning weakens the tree due to the reduction in foliage mass (Meier et al. 2012) and it can stress and expose more meristematic tissue to increased light levels (Fink 1984). shoots originating from a cluster (b); Pec number of points where multiple shoots originate from (points of origin) (c)

\subsection{Hypothesis no. 2}

According to hypothesis no. 2, the number of new epicormic shoots decreases with increasing stand density. This study observed an increasing number of new epicormic shoots with increasing stand density, contrary to $\mathrm{H} 2$.

Previous research indicates that, compared to mediumdensity stands, the number of epicormic shoots is higher in very dense stands (Fontaine et al. 2001). For heavily thinned
Table 5 Summary of fixed, random and variance estimated parameters for the thinning analysis. Section represents the intercepts for each stem section.

Section $\times$ trees per hectare represent the different slopes adjusted for the interaction. The random effect $a_{k}$ representing the within tree variation is $N\left(0,0.677^{2}\right)$ and the random effect $b_{j k}$ representing the between-tree variation is $N(0$, $\left.3.159^{2}\right)$. Estimates for the fixed effect for sections other than section 1 were estimated as an adjustment to the section 1 estimate

\begin{tabular}{|c|c|c|c|c|c|}
\hline Fixed & Estimate & $\mathrm{SE}$ & $d f$ & $t$ value & $p$ value \\
\hline Section 1 & 2.622 & 0.84 & 685 & 3.130 & 0.003 \\
\hline Section 2 & -2.108 & 1.34 & 685 & 1.570 & 0.117 \\
\hline Section 3 & -0.245 & 0.95 & 685 & 0.257 & 0.797 \\
\hline Section 4 & 1.059 & 0.76 & 685 & -1.388 & 0.166 \\
\hline Section 5 & 2.051 & 0.76 & 685 & -2.708 & 0.007 \\
\hline Section 6 & 2.501 & 0.78 & 685 & -3.223 & 0.001 \\
\hline Section $1 \times$ trees $^{-1}$ & 0.001 & 0.00 & 685 & 2.479 & 0.014 \\
\hline Section $2 \times$ trees ha $^{-1}$ & -0.002 & 0.00 & 685 & 1.938 & 0.053 \\
\hline Section $3 \times$ trees ha $^{-1}$ & -0.001 & 0.00 & 685 & 1.791 & 0.074 \\
\hline Section $4 \times$ trees $^{-1}$ & 0.000 & 0.00 & 685 & 0.050 & 0.960 \\
\hline Section $5 \times$ trees ha $^{-1}$ & 0.000 & 0.00 & 685 & 0.412 & 0.681 \\
\hline Section $6 \times$ trees $^{-1}$ & 0.000 & 0.00 & 685 & -0.969 & 0.333 \\
\hline \multicolumn{6}{|c|}{ Random-variance covariate } \\
\hline$\sigma^{2}$ section 1 & 26.774 & & & & \\
\hline$\sigma^{2}$ section 2 & 68.476 & & & & \\
\hline$\sigma^{2}$ section 3 & 21.224 & & & & \\
\hline$\sigma^{2}$ section 4 & 3.951 & & & & \\
\hline$\sigma^{2}$ section 5 & 3.542 & & & & \\
\hline$\sigma^{2}$ section 6 & 5.040 & & & & \\
\hline
\end{tabular}


Fig. 4 Scatter plot of the observed number of epicormic shoots vs. stand density. Each regression line represents a stem section

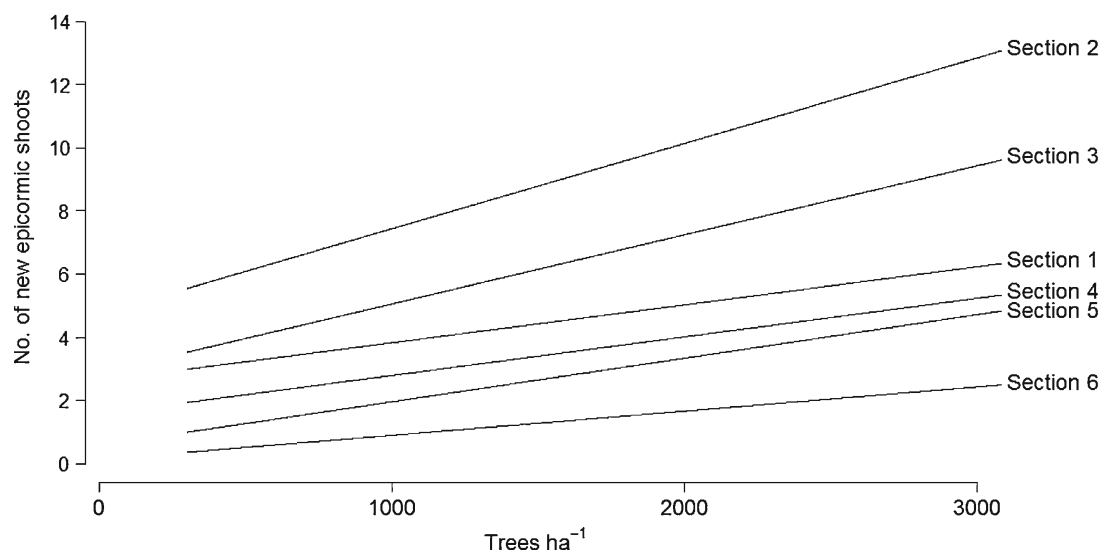

stands, there are contrasting results indicating both more (Ward 1966; Jobling and Pearce 1977; Kerr 1996) and less (Morisset et al. 2011b) epicormic shoots.

The higher number of epicormic shoots in very dense stands can be explained by the social hierarchy, more suppressed trees and more intense competition triggering the production of epicormic shoots. For heavily thinned stands and free growth oak, light is obviously an important factor and it is possible that between-tree variation in the shading from individual crowns may help explain the contrasting results. Some studies have demonstrated a statistically significant effect for different intermediate thinning practices (Colin et al. 2010), while others (Wignall and Browning 1988; Fontaine et al. 2001) have not. With this in mind, light and the genetic characteristics of individual trees again become the factors of interest. There is an issue with the growth and persistence of epicormic shoots, which has been investigated partially for oak. For four different stand densities, the conclusion was that new shoots emerge due to different light environments, but then gradually die with increasing canopy closure (Spiecker 1991).

\subsection{Hypothesis no. 3}

According to hypothesis no. 3, the number of new epicormic shoots increases with increasing height up the stem. In this study, the number of new epicormic shoots instead decreased with increasing height up the stem in both the pruning and the thinning analyses. This leads to a rejection of hypothesis no. 3.

In pruned trees, the decrease is not linear, but sections 4 $6 \mathrm{~m}$ generally had less epicormic shoots than the lower sections. However, un-pruned trees presented a steady decrease with increasing height up the stem. Due to the significant interaction between pruning and section, pruned trees have more epicormic shoots closer to the canopy than un-pruned trees. There are several possible explanations for this: more light penetrates through to the upper stem sections of pruned trees or that hormonal regulation triggers the emergence of more epicormic shoots near the lower canopy branches. Here, more primary branches were removed, creating callus tissue, and consequently more epicormic shoots emerged. Most of these are probably of adventitious origin.

The interaction also highlighted the contrast between the within-plot competition, quantified in the second part of the analysis, and the positive effect of shading due to the size of individual crowns, resulting in a lower number of epicormic shoots in the stem sections (4-6 m) close to the canopy. In addition, the preliminary analysis showed that the number of primary and secondary branches removed with pruning had an effect on the composition of new epicormic shoots (single vs. cluster). This could possibly explain the larger variation and fluctuation from the third to the fifth stem section of pruned trees (Fig. 2). Moreover, the quantity of foliage is reduced when trees are pruned, implying a potentially different allocation of photosynthetic products within the tree.

For thinning, a similar trend was found, showing a consistent decrease of new epicormic shoots with increasing height up the stem, across different stand densities. This is in contrast to the findings of Henriksen and Sanojca (1983), Smith (1965), Spiecker (1991) and Ward (1966), who all found an increase in the number of epicormic shoots with increasing height above ground. A possible explanation is that they studied much older trees and that the location effect could be age dependent. Moreover, they had no replicate experiments, and while Henriksen and Sanojca (1983) worked with pedunculate oak, both Smith (1965) and Ward (1966) investigated American oaks. Consequently, $\mathrm{H} 3$ should be revised to test experimentally whether the indication of an age effect is valid in general.

\subsection{Additional issues}

Surprisingly, DBH and $\mathrm{H}$ were not significant in any model. This finding contrasts the results reported by Nicolini et al. (2001), but is in agreement with Harmer (1990, 1992), Colin et al. (2008) and Morisset et al. (2012) who stated that the occurrence or emergence of epicormic shoots is unrelated to the size of individual trees. This might be due to individual tree 
variation (hence, the significant random component in the model), since epicormic shoots have a strong genetic component among families of Q. robur (Savill and Kanowski 1993) and the production is partly under genetic control (Jensen 2000), or due to the different diameter classes investigated in other studies. Furthermore, certain individual trees consistently bear more epicormic shoots over time independent of the thinning practice, as reported by Henriksen and Sanojca (1983), Ward (1966), Morisset et al. (2011b) and Spiecker (1991).

Considering the social status of a tree, it was noticed during field work that suppressed trees had in general a larger number of epicormic shoots, supporting a number of previous observations (Krajicek 1959; Nicolini et al. 2001; Spiecker 1991). Even though tree size variables were not significant in predicting new epicormic shoots, it cannot be inferred that tree social status is not of importance as data were not collected to test this hypothesis. Consequently, there is a missing link between the relationship among tree size, social status and the composition of epicormic shoots.

\subsection{Implications for silviculture}

The results presented in this paper indicate that early, heavy thinning combined with high pruning, initiated early and repeated at regular intervals, may help to shorten the rotation length for pedunculate oak without a further reduction in wood quality than which is due to wider annual growth rings. The lower number of epicormic shoots with decreasing stem density indicates that heavy thinning is economically opti$\mathrm{mal}$ in terms of pruning costs. It remains to be tested, however, whether these conclusions hold for a wider range of site types, oak genotypes and throughout a full rotation and how the persistence of epicormic shoots changes. It also remains to be clarified which range of stand densities is optimal considering density-dependent production risks and the range of management objectives (or components thereof) that may be relevant for the sustainable production of highquality oak timber.

Acknowledgments Thanks are due to Professor Jens Peter Skovsgaard (Swedish University of Agricultural Sciences) for inspirational supervision and valuable comments on the draft manuscript and Clémentine Ols (Swedish University of Agricultural Sciences) for the helpful suggestions provided during fieldwork and writing. Dr. Christian Ritz (University of Copenhagen) most kindly provided additional statistical advice during the research process.

Funding The establishment and maintenance of experiments 1516 and 1517 were supported during 2002-2007 by two grants from the Danish Nature Agency's fund for experimental silviculture. The University of Copenhagen provided institutional support for the experiments. The research presented in this paper was supported during 2010-2013 by basic funding from the Swedish University of Agricultural Sciences.

\section{References}

Bary-Lenger A, Nebout JP (1993) Le chêne. Editions du Perron, AlleurLiège

Carbonnier C (1975) Produktionen i kulturbestånd av ek i södra Sverige. Studia Forestalia Suecica 125:1-89

Colin F, Robert N, Druelle JL, Fontaine F (2008) Initial spacing has little influence on transient epicormic shoots in a 20 -year-old sessile oak plantation. Ann For Sci 65:508-517

Colin F, Mechergui R, Dhôte JF, Fontaine F (2010) Epicormic ontogeny on Quercus petraea trunks and thinning effects quantified with the epicormic composition. Ann For Sci 67:813

European standard EN 975-1 (2009) Grading of oak sawn timber — appearance grading. http://en.eurochene.com/_medias/websites/eurochene-en/ storage/european-oak-grading-rules-qf1a-qf1b_396.pdf. Accessed 20 May 2013

Evans J (1982) Free growth and control of epicormics. In: Malcolm DC, Evans J, Edwards PN (eds) Broadleaves in Britain. Institute of Chartered Foresters, Edinburgh, pp 183-190

Evans J (1984) Silviculture of broadleaved woodland. For Comm Bull 62:1-232

Fink S (1983) The occurrence of adventitious and preventitious buds within the bark of some temperate and tropical trees. Am J Bot 70:532-542

Fink S (1984) Some cases of delayed or induced development of axillary buds from persisting detached meristems in conifers. Am J Bot 71:44-51

Fontaine F, Kiefer E, Clement C, Burrus M, Druelle JL (1999) Ontogeny of the proventitious epicormic buds in Quercus petraea. II. From 6 to 40 years of the tree's life. Trees Struct Funct 14:83-90

Fontaine F, Colin F, Jarret P, Druelle JL (2001) Evolution of the epicormic potential on 17-year-old Quercus petraea trees: first results. Ann For Sci 58:583-592

Fontaine F, Mothe F, Colin F, Duplat P (2004) Structural relationships between the epicormic formations on the trunk surface and defects induced in the wood of Quercus petraea. Trees Struct Funct 18:295-306

Harmer R (1990) The timing of canopy and epicormic shoot growth in Quercus robur L. Forestry 63:279-283

Harmer R (1992) Do dominant oaks have few epicormic branches? Forestry Commission Research Information Note 223

Henriksen HA (1988) Skoven og dens dyrkning. Dansk Skovforen. Nyt Nordisk Forlag Arnold Busck, København

Henriksen HA, Sanojca K (1983) Bøgeunderskovs betydning for udvikling af vanris på stilkeg (Quercus robur L.) Det forstlige Forsøgsvæsen i Danmark 39:93-119

Jarret P (2004) La chênaie atlantique. Office national des forêts, Paris

Jensen JS (2000) Provenance variation in phenotypic traits in Quercus robur and Quercus petraea in Danish provenance trials. Scan J For Res 15:297-308

Jensen FS, Skovsgaard JP (2009) Precommercial thinning of pedunculate oak: recreational preferences of the population of Denmark for different thinning practices in young stands. Scan J For Res 24:28-36

Jobling J, Pearce ML (1977) Free growth of oak. For Comm For Rec 113:1-17

Kenk GK (1993) New perspectives in German oak silviculture. Ann For Sci 50:563-570

Kerr G (1996) The effect of heavy or 'free growth' thinning on oak (Quercus petraea and Q. robur). Forestry 69:303-317

Kerr G, Harmer R (2001) Production of epicormic shoots on oak (Quercus robur): effects of frequency and time of pruning. Forestry 74:467-477

Krajicek JE (1959) Epicormic branching in even-aged undisturbed white oak stands. J For 57:372-373 
Lemaire J (2010) Le chêne autrement: Produire du chêne de qualité en moins de 100 ans en futaie régulière. Guide technique. Institut pour le développement forestier: Centre national de la propriété forestière, Paris

Meier AR, Saunders MR, Michler CH (2012) Epicormic buds in trees: a review of bud establishment, development and dormancy release. Tree Physiol 32:565-584

Morisset JB, Mothe F, Chopard B, Francois D, Fontaine F, Colin F (2011a) Does past emergence of epicormic shoots control current composition of epicormic types? Ann For Sci 69:139-152

Morisset JB, Mothe F, Bock J, Bréda N, Colin F (2011b) Epicormic ontogeny in Quercus petraea constrains the highly plausible control of epicormic sprouting by water and carbohydrates. Ann Bot 109:365-377

Morisset JB, Mothe F, Colin F (2012) Observation of Quercus petraea epicormics with X-ray CT reveals strong pith-to-bark correlations: silvicultural and ecological implications. For Ecol Manag 278:127137

Nicolini E, Chanson B, Bonne F (2001) Stem growth and epicormic branch formation in understorey beech trees (Fagus sylvatica L.). Ann Bot 87:737-750

O'hara K (2007) Pruning wounds and occlusion: a long-standing conundrum in forestry. J For 105:131-138

Pinheiro J, Bates D, DebRoy S, Sarkar D, the R Development Core Team (2012) nlme: linear and nonlinear mixed effects models. $R$ package version $3.1-103$

R Core Team (2012) R: a language and environment for statistical computing. R Foundation for Statistical Computing, Vienna, Austria. ISBN 3-900051-07-0, URL http://www.R-project.org/. Accessed 2 Feb 2013

Röhrig E, Bartsch N, von Lüpke B, Dengler A (2006) Waldbau auf ökologischer Grundlage. Eugen Ulmer Verlag, Stuttgart

Roussel L (1978) Lumiere, gourmands et rejets de souches. Rev For Fr 3:186-200
Rune F, Skovsgaard JP (2007) Afforestation with oak: effects of precommercial thinning on the development of ground flora. TemaNord 508:203-209

Sardin T (2008) Chênaies continentales. Office national des forêts, Paris

Savill PS, Kanowski PJ (1993) Tree improvement programs for European oaks-goals and strategies. Ann For Sci 50:368383

Skovsgaard JP (2004a) Produktion af kvalitetstræ i eg: et eventyr om hovedtræer og vanris. Skoven 36:528-531

Skovsgaard JP (2004b) Produktion af kvalitetstræ i eg: er eventyret bæredygtigt? Skoven 36:532-535

Smith HC (1965) Effects of clearcut openings on quality of hardwood border trees Liriodendron tulipifera, Quercus rubra, Prunus serotina. J For 63:933-937

Spiecker H (1991) Controlling the diameter growth and the natural pruning of sessile and pedunculate oaks (Quercus petraea (MATT.) LIEBL. and Quercus robur L). Dissertation, Selbstverlag der Landesforstverwaltung Baden-Württemberg

Ståål E (1986) Eken i skogen och landskapet. Södra skogsägarna, Växjö

Staun H (1989) Intensiv egedyrkning. Dan Skovbrugs Tidsskr 74:87-112

Stern RC (1973) The production of high value hardwoods. Timber Grow 48:11-21

Ward WW (1966) Epicormic branching of black and white oaks. For Sci 12:290-296

West BT, Welch KB, Gałecki AT (2007) Linear mixed models: a practical guide using statistical software. Chapman \& Hall/CRC Press, Boca Raton

Wignall TA, Browning G (1988) The effects of stand thinning and artificial shading on epicormic bud emergence in pedunculate oak (Quercus robur L). Forestry 61:45-59

Zuur AF, Ieno EN, Walker NJ, Saveliev AA, Smith GM (2009) Mixed effects models and extensions in ecology with $\mathrm{R}$ (statistics for biology and health). Springer, New York 